Bangl. J. Vet. Med. (2010). 8(1): 63 - 73

\title{
EFFECTS OF SELENIUM AND VITAMIN B 6 WITH THEIR COMBINATION IN LEAD ACETATE INDUCED TOXICITIES IN LONG EVANS RATS
}

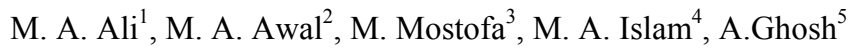 \\ ${ }^{1}$ MS Student, ${ }^{2 \& 3}$ Professor, ${ }^{5} \mathrm{PhD}$ Student, Department of Pharmacology, ${ }^{4}$ Department of Animal Science, \\ Bangladesh Agricultural University, Mymensingh-2202
}

\begin{abstract}
The experiment was performed on 75 long Evans male rats (Rattus norvegicus), weighing about 145 -170 gm, maintained under standard laboratory condition on pellet diet and drinking water ad libitum. All the rats were randomly divided into five equal groups. Each group comprised of fifteen (15) rats and were marked as group A, B, C, D and E. Group A without treatment, group B lead acetate alone @ $20 \mathrm{mg} / \mathrm{kg}$ b.wt., group C lead acetate @ $20 \mathrm{mg} / \mathrm{kg}$ b.wt. plus sodium selenite $5 \mathrm{ml}$ (from a stock solution $1.5 \mathrm{mg}$ diluted in 1 litre distilled water), group D lead acetate @ $20 \mathrm{mg} / \mathrm{kg}$ b.wt. plus vitamin $\mathrm{B}_{6} 45$ $\mathrm{mg} / \mathrm{kg}$ b.wt., group E lead acetate @ $20 \mathrm{mg} / \mathrm{kg}$. b.wt. plus sodium selenite $5 \mathrm{ml}$ (from a stock solution $1.5 \mathrm{mg}$ diluted in 1 litre distilled water) plus vitamin $\mathrm{B}_{6} 45 \mathrm{mg} / \mathrm{kg}$ b.wt. All treatments were given once daily for 28 consecutive days. In the present study, the effect of sodium selenite and vitamin $\mathrm{B}_{6}$ in lead induced toxicities in rats were observed. Toxic signs and body weight change, haematological parameters like Total Erythrocyte Count (TEC), Total Leukocyte Count (TLC), hemoglobin content $(\mathrm{Hb} \%)$ and Packed Cell Volume (PCV), biochemical parameters such as Serum Glutamate Pyruvate Transaminase SGPT/ALT, Serum Glutamate Oxaloacetate Transaminase (SGOT/AST) and postmortem changes in rats were investigated. Rats treated with lead acetate showed severe toxic signs and significantly $(\mathrm{p}<0.01)$ reduced TEC, TLC, Hb\% and PCV. Significant $(\mathrm{p}<0.01)$ elevation of SGPT and SGOT were also found. But rats treated with lead acetate along with sodium selenite and vitamin $\mathrm{B}_{6}$ showed almost normal levels of haematological and biochemical parameters. Lead acetate produces congestion and necrosis in liver, spleen and kidney, whereas simultaneous use of lead acetate, sodium selenite and vitamin $\mathrm{B}_{6}$ recovered the condition. From this experiment it is revealed that combine use of sodium selenite and vitamin $\mathrm{B}_{6}$ is highly protective against lead toxicity.
\end{abstract}

Key words: Rats, sodium selenite, lead acetate, vitamin $\mathrm{B}_{6}$

\section{INTRODUCTION}

Lead is a persistent and common environmental contaminant. It is a ubiquitous metal that has been used by humans for more than 3 millennia. Use of lead in gasoline and house paint in the USA are very common although these items are no longer made with lead. In the past, lead has been used as an anti-knock, lubricating additive in gasoline and as a pigment in paints. Lead is still commonly found in older pipes, brass faucets or pipes with soldered fittings. Lead is also found in automotive batteries, fishing weights and has long been the preferred material for use in shot and bullets. Like other commonly found persistent toxic metals such as mercury, arsenic, and cadmium, lead damages cellular material and alters cellular genetics. Its toxic effects on humans are well documented in history (Patrick, 2006). Lead has been recognized as toxic for over a thousand years and still causes poisoning in people, wildlife, and domestic animals. Lead poisoning is one of the most common toxicants in cattle. However, lead poisoning can occur in all domestic animals including horses, birds/poultry and dogs. Pigs are the least susceptible (Bob, and the Texas Farm Bureau, 2004). Lead is a heavy metal that is present in petrol and octane has been known for many years to produce toxic effects on the central nervous systems. Erythrocytes have a high affinity for lead, binding 99 percent of the lead in the bloodstream. Lead has a destabilizing effect on cellular membranes, and in red blood cells (RBC). It decreases cell membrane fluidity and increases the rate of erythrocyte hemolysis. Hemolysis appears to be the end result of ROS-generated lipid peroxidation in the RBC membrane. Lead can also bind directly to phosphatidylcholine in the RBC membrane, leading to a decrease in phospholipid levels. Lipid peroxidation of cellular membranes has also been identified in tissue from various regions of the brain of lead-exposed rats. Hypochromic or normochromic anemia is a hallmark of lead exposure; it results from ROS generation and subsequent erythrocyte hemolysis (Patrick, 2006). Ascorbic acid, thiamine or their combination in experimental lead intoxication in albino rat 


\section{M.A. Ali and others}

lower concentration of lead in the blood. The combination of both vitamins was most effective in reducing leadinduced inhibition of blood $\delta$-amino levulinic acid dehydratase by elevating urinary excretion of $\delta$-amino levulinic acid. The combined treatment during and following lead exposure was more effective in restoring leadinduced biochemical alterations and im mobilizing of lead from tissues (Anguelov et al., 2002).

The simultaneous administration of lead and thiamine reduces the uptake of lead in tissues and prevents the clinical signs of lead poisoning in calves (Bratton et al., 1981). The supplementation of vitamin B complex also diminishes lead induced biochemical alterations in urine, blood, kidney and liver and the tissue accumulation of lead in rats. Dietary supplementation of iron and ascorbic acid prevents lead induced growth retardation, anemia, renal hypertrophy and the accumulation of lead in tissues (Suzuki and Yoshida, 1979a). Many scientists studied on the efficacy of thiamine, ascorbic acid, and becozinc (a pharmacological preparation containing vitamins of the B complex group, garlic and zinc) in enhancing excretion and reducing tissue burden of lead and reversing lead-sensitive bio-chemical alterations was investigated in lead pre-exposed-mice. These vitamins were effective in mobilizing lead from blood, liver, and kidney into urine and/ or faeces and in restoring partially blood zinc protoporphyrin level (Tandon and Singh, 2000). Selenium is a required mineral for the metallo-enzyme glutathione peroxidase (GPx). GPx plays a key role in recycling glutathione and is effective in reducing free radical damage in specific disease states. Selenium supplementation has been shown to have a protective effect when given prior to lead exposure in animals (Patrick, 2006). Increased levels of superoxide dismutase (SOD), glutathione reductase, and reduced glutathione occurred in both liver and kidney tissue after intramuscular injection of sodium selenite. These effects continued even after exposure to lead in rats that had been pre-treated with selenium. Lead can bind to selenium and form highly bonded selenium-lead complexes, which have been proposed as a mechanism for selenium's protective effect in lead toxicity.

Sodium selenite supplementation with pyridoxine in lead-exposed rats improved amino levulinic acid dehydratase (ALAD) activity and blood, kidney, and liver levels of lead were also reduced, while brain levels remained stable. The proposed mechanism of pyridoxine in lead toxicity relates to its role in the metabolic transsulfuration pathway, which allows for the metabolism of cysteine from methionine. Methionine is the main dietary source of cysteine, the rate-limiting amino acid in glutathione production. Lead-exposed rats having vitamin $\mathrm{B}_{6}$ deficiencies had significantly lower glutathione levels than lead-exposed rats with normal vitamin $\mathrm{B}_{6}$ levels (Patrick, 2006). In the present study an attempt has been under taken to study the effect of selenium and vitamin $\mathrm{B}_{6}$ in lead induced toxicities in rats with the aim to observe the toxic signs and body weight, some hematological parameters like, Total Erythrocyte Count (TEC), Total Leukocyte Count (TLC), Packed Cell Volume (PCV) and hemoglobin content (Hb), some biochemical parameters such as Serum Glutamate Pyruvate Transaminase (SGPT)/ALT, Serum Glutamate Pyruvate Oxaloacetate Transaminase (SGOT)/AST, postmortem changes and lead content in different organs like blood, liver, kidney, brain, femur in rats.

\section{MATERIALS AND METHODS}

\section{Place of Experiment and Experimental Animal}

The study was conducted on 75 rats weighing about 145-170 g, maintained on standard laboratory condition with pellet diet (ICDDR, B) and drinking water ad-libitum. The rats were collected from Department of Pharmacology, Bangabandhu Sheikh Mujib Medical University (BSMMU), Dhaka. The rats were kept under close observation for a period of seven days in order to maintain good health for conducting experiment properly. All the rats were kept in a compartmented rectangular metallic and well-ventilated animal cages wrapped with wire mesh with relative humidity of $70-80 \%$ and at $28 \pm 2^{\circ} \mathrm{C}$ temperature. The room lighting consisted of alternate 12 hours light and dark periods. After observation, all the rats were randomly divided into five (05) equal groups. Each group comprised of fifteen (15) rats and was marked as groups A, B, C, D and E. All rats were subjected to treat with the help of a measuring dropper once daily for a period of four weeks.

\section{Preparation of solution}

Required amount of lead acetate and vitamin $\mathrm{B}_{6}$ were diluted in $5 \mathrm{ml}$ distilled water and $1.5 \mathrm{mg}$ sodium selenite was diluted in 1 litre distilled water and were administered daily orally. 


\section{Layout of the Experiment:}

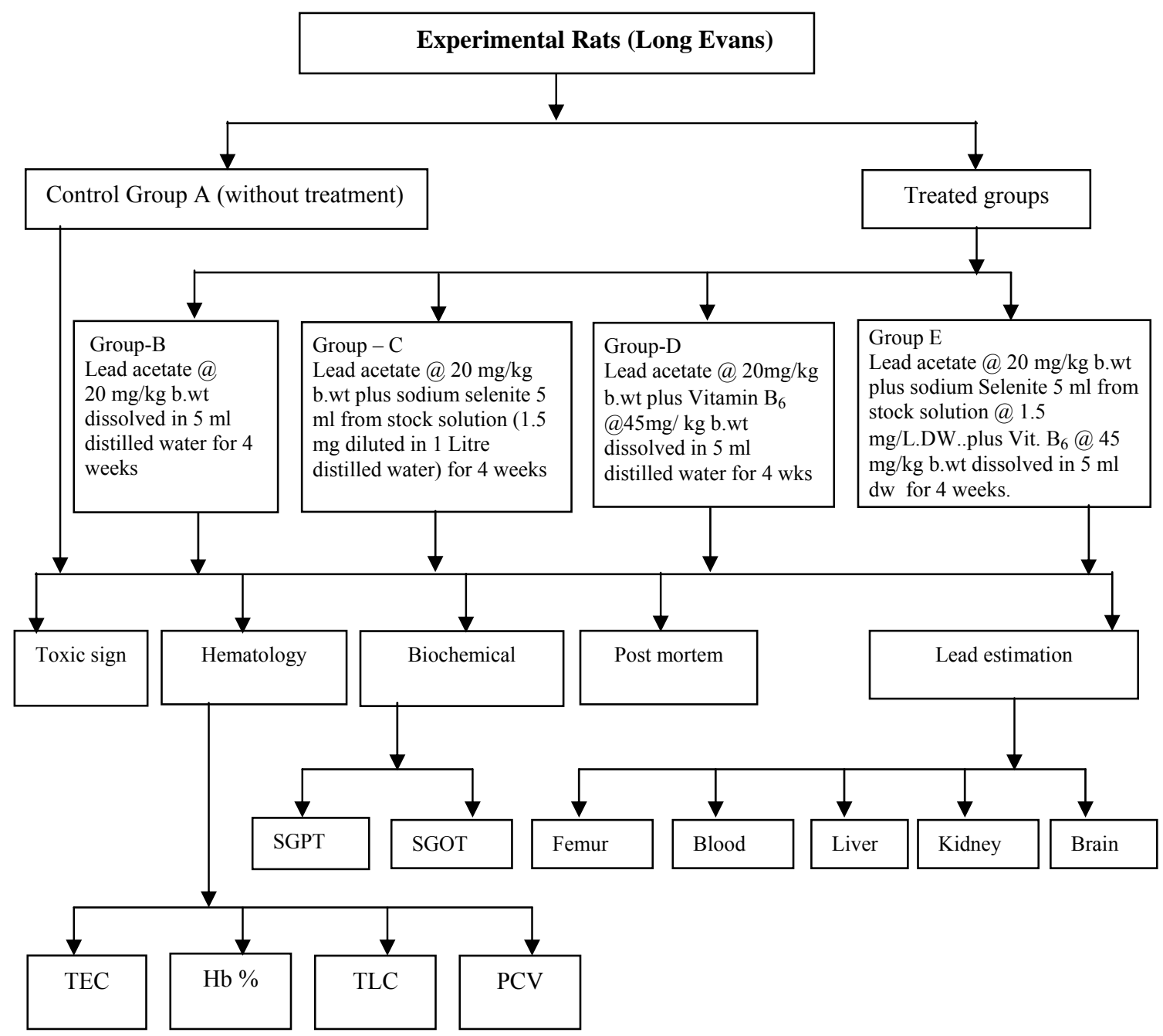

\section{Collection of blood sample}

For determining hematological and biochemical parameters $4.5 \mathrm{ml}$ blood were collected from each rats of 25 rats (from 75 rats of rats group A, B, C, D and E) with aseptic precaution at 0 day (immediate previous day of treatment). Rats were starved and anaesthetized with chloroform and blood samples were collected directly from heart with the help of disposable syringe and needle by opening abdominal cavity and then the rats were sacrificed and were dissected to observe the post mortem changes. Immediately after collection of $1.5 \mathrm{ml}$ blood, was transferred to sterile test tube containing anticoagulant at a ratio of 1:10 for hematological examination. The rest $(3 \mathrm{ml})$ blood of each rat was then transferred in separate sterile glass test tube. After clotting, the attachment of the clot to the wall of the test tube was detached by a long fine needle moving slowly in between the clot and test tube wall up to the bottom of the tube. Then the test tubes with clot were kept overnight at ${ }^{\circ} \mathrm{C}$ in a refrigerator. In the next morning, the test tubes were centrifuged in a centrifuge machine (Hettich, Universal II, and Germany) at 1500 rotation per minute (rpm) for 15 minutes. The supernatant sera were collected by individual sterile Pasteur pipette into corresponding marked sterile tubes and kept at $-20^{\circ} \mathrm{C}$ in deep freeze until tested. At day 14 and at day 28 of treatment blood sample collection was done gradually from the rest of the rats (50) of group A, B, C, D and E at the same procedure above. 


\section{M.A. Ali and others}

\section{Haematological parameters}

The collected blood was used for different hematological parameters within two hours of collection. The hematological parameters were determined as per method cited by Lamberg and Rothstein (1977). The detail procedures were as followed:

\section{A. Total Erythrocyte Count (TEC)}

For determination of TEC blood samples were drawn with red blood cell diluting pipette exactly up to 0.5 mark of the pipette. Outside of the tip of the pipette was wipped with cotton. Then the tip of this pipette was immediately placed into the red cell diluting fluid (Hayem's solution) and the pipette was filled with the fluid up to 101 marks.

- $\quad$ The contents of the pipette were mixed thoroughly by shaking with 8-knot motion for 3-5 minutes.

- After discarding 2 or 3 drops of fluid from the pipette a small drop was placed to the edge of the cover glass on the counting chamber and the area under the cover glass was filled by the fluid introduced.

- One-minute time was spared to allow the cells to settle over the chamber uniformly and then the cells were counted from the recognized 80 small squares.

- $\quad$ After completion of counting total cells, the number of RBC recorded from the supplied samples were expressed as number of cells counted $\times 10,000$ and the result was expressed in million/cu. mm. of blood (Lamberg and Rothstein, 1977).

\section{B. Total Leukocyte Count (TLC)}

The principles involved in enumeration of Total Leukocyte Count were almost same to those of erythrocytes. Here the leukocyte diluting fluid was used N/10 HCl. Well mixed blood was drawn upto the 0.5 mark of while blood cell pipette. The diluting fluid was filled upto the 11 mark of the pipette and the contents were thoroughly mixed for 2 minutes. Two or three drops of contents were discarded and counting chamber was then filled in the same way as in the RBC count. The counting chamber was placed under the microscope and examined under low power objective $(10 \mathrm{x})$. The leukocytes in the large squares (each 1 square $\mathrm{mm}$ ) of the counting chamber were counted. The number of W. B. C. was calculated as follows: Number of WBC $=$ No. of cell counted $\times 10$ and the result is expressed in thousand per cu $\mathrm{mm}$.

\section{Packed Cell Volume (PCV)}

The citrated blood was drawn into special loading pipette (wintrobe pipette). The tip of the pipette was inserted to the bottom of a clean, dry wintrobe hematocrit tube. The rubber bulb of the pipette was pressed continuously to expel the blood out of the pipette and the wintrobe hematocrit tube was filled from the bottom. As blood came out, the pipette was slowly withdrawn but pressure was continued on the rubber bulb of the pipette so as to exclude air bubbles. The tip of the pipette was tried to keep under the rising column of blood to avoid foaming and the tube was filled exactly to the $10 \mathrm{~cm}$ mark. The wintrobe tubes were placed in the centrifuge machine and were centrifuged for 30 minutes @ 3000 rpm. Then, the hematocrite or PCV was recorded; the percent volume occupied by the hematocrit was calculated by using the following formula as described by Lamberg and Rothstein (1977).

$\mathrm{PCV} \%=\frac{\text { Height of the red cell volume in } \mathrm{cm}}{\text { Height of total blood in } \mathrm{cm}} \times 100$

\section{Determination of hemoglobin content (acid hematin method)}

- $\quad$ N/10 hydrochloric acid was taken in a graduated tube up to 2 marks with the help of a dropper.

- $\quad$ Citrated well-homogenized blood was than drawn into the Sahli pipette up to $20 \mathrm{~cm}$. mark.

- The tip of the pipette was wipped with sterile cotton and the blood of the pipette was immediately transferred into the diluting tube containing hydrochloric acid solution.

- The pipette was rinsed 2-3 times by sucking fluid into the tube. This blood and acid were thoroughly mixed by a glass stirrer into the diluting tube. There was a formation of acid hematin mixture in the tube by the hemolysed red blood corpuscle and hydrochloric acid (HCL).

- $\quad$ The tube containing acid hematin mixture was kept standing in the comparator for 5 minutes. After that distilled water was added drop by drop.

- The solution was mixed well with a stirrer until the color of the mixture resembled with the standard color of the comparator. 
Effects of selenium and vitamin $b_{6}$ with their combination in lead acetate induced toxicities in rats

- The result was read in daylight by observing the height of the liquid in the tube considering the lower meniscus of the liquid column. The result was then expressed in gm\%. The above procedure was matched by the Hellige hemometer method as described by Coffin (1955).

\section{Biochemical parameters}

The biochemical parameters were determined according to the method described by Denecke and Rittersdorf (1984) and Denecke et al. (1985) by using Reflotron ${ }^{\circledR}$ (Boehringer mannheim, Germany).

Following biochemical parameters were studied

a. Serum Glutamate Oxaloacetate Transaminase (SGOT/AST).

b. Serum Glutamate Pyruvate Transaminase (SGPT/ALT).

\section{A. Determination of SGOT/AST}

\section{Procedure}

In brief, serum of the sample was 4-fold diluted in Phosphate Buffer Solution (PBS) with pH 7.4. Twenty five $\mu l$ of diluted serum of blood was taken with the help of a capillary pipette avoiding any bubbles and was placed to the centre of the GOT test strip after removing the outer coverings of the strip. Care was taken in such a way that the tip of the pipette could not touch the application zone of the test strip. After opening the sliding cover of the machine, the test strip was placed on to the guide within 15 second and the test strip was forwarded until it locks into place. The sliding cover was closed properly. The GOT level of displayed on the monitor automatically after 1-2 minutes. The enzyme activity was expressed in U/L.

\section{B. Determination of SGPT/ALT \\ Procedure}

SGPT is determined following the same procedure as done in case of SGOT. Serum sample was 4-fold diluted in Phosphate Buffer Solution (PBS) with pH 7.4. Twenty five $\mu 1$ of diluted serum of blood was taken with the help of a capillary pipette avoiding any bubbles and one drop was placed to the centre of the red application zone (xx) of the GPT test strip after opening the sliding cover of the strip. Within 15 second strip was placed on to the guide after opening the sliding cover of the machine and test strip was forwarded until it locks into place. Then the sliding cover was closed. The GPT level was displayed on the monitor within 2-3 minutes. The enzyme activity was expressed in U/L.

\section{Estimation of lead acetate in different organs of the body}

The different tissues and organs (blood, liver, kidney, brain and femur) were collected aseptically by washing in normal saline and stored at $-20^{\circ} \mathrm{C}$ in deepfreeze for future detection of lead in collected tissues. Tissues and organs were homogenized according to the following procedure:

\section{A. Preparation of tissue homogenates}

Individual organs were taken aseptically and were grinded with the help of mortar and pestle in normal saline and then the tissue materials (homogenates) were taken in different test tubes. Normal saline was added at the rate of $5 \mathrm{ml}$ per grams of tissues. For blood samples, normal saline was also added at the rate of $5 \mathrm{ml}$ per $\mathrm{ml}$ of blood.

\section{B. Semi quantitative lead determination by "Merck Lead Test” kit (Merck, Germany)}

"Merck Lead Test" kit is most suitable for the determination of metallic lead/lead compounds in waters, soil extracts, pharmaceuticals, prepared biological materials and in liquid foods. This test may also be used in a number of fraction processes to check the concentration of lead compounds and for monitoring the limits in electrical components, catalysis, special types of glass and certain electroplating baths.

\section{Reaction principle}

Lead in acidic solution can reacts with rodizonic acid to form a red colored complex.

\section{Procedure}

i. The test vessel was washed with deionized water and finally rinsed with the tissue homogenate to be tested and was filled up to the $5 \mathrm{ml}$ mark.

ii. Three drops of reagent was added to the test tube and was carefully mixed thoroughly.

iii. The reaction zone of the test strip was dipped in the tissue homogenate to be tested for one second in such a way that the reaction zone was properly wetted.

iv. Excess liquid from the strip was shocked.

v. The reaction zone of the test strip was compared with the colour scale after 2 minutes. 


\section{M.A. Ali and others}

\section{Statistical Analysis}

Data obtained from the experiment on body weight, hematological and biochemical parameters were expressed as Mean \pm SE and analyzed statistically using Students ' $t$ ' test.

\section{RESULTS}

\section{Effects on body weight}

The mean body weight of rats of group B and C was significantly $(\mathrm{p}<0.01)$ decreased but in group $\mathrm{C}$, it was less significant $(\mathrm{p}<0.05)$ at $28^{\text {th }}$ day of treatment. In group $\mathrm{D}$ the reduction of mean b.wt. was not statistically significant at $14^{\text {th }}$ day of treatment but significant $(\mathrm{p}<0.05)$ at $28^{\text {th }}$ day of treatment. However, in group E, b.wt. was very slightly reduced during the experiment which was not statistically significant (Table 1).

Table 1. Effects of sodium selenite, vitamin $B_{6}$ and a combination of sodium selenite with vitamin $B_{6}$ in lead induced toxicities on body weight ( $\mathrm{gm}$ ) of rats

\begin{tabular}{|c|c|c|c|c|}
\hline \multirow{2}{*}{ Group } & \multirow{2}{*}{ Dose } & \multicolumn{3}{|c|}{ Weight (gm) } \\
\hline & & Day 0 & Day 14 & Day 28 \\
\hline $\mathrm{A}$ & Control (no treatment) & $147.52 \pm .80$ & $\begin{array}{l}148.52 \pm .83 \\
(.68 \%) \uparrow\end{array}$ & $\begin{array}{l}150.22 \pm .85 \\
(1.15 \%) 4\end{array}$ \\
\hline B & $\begin{array}{l}\text { Lead acetate @ } 20 \mathrm{mg} / \mathrm{kg} \text { b.wt dissolved in } \\
5 \mathrm{ml} \text { dist.water. }\end{array}$ & $149.20 \pm .80$ & $\begin{array}{l}127.80 \pm .93^{* *} \\
(14.34 \%) \downarrow\end{array}$ & $\begin{array}{l}115.20 \pm 1.48 * * \\
22.78 \% \downarrow\end{array}$ \\
\hline $\mathrm{C}$ & $\begin{array}{l}\text { Lead acetate @ } 20 \mathrm{mg} / \mathrm{kg} \text { b.wt dissolved in } \\
5 \mathrm{ml} \text { Dist. water plus sodium selenite } 5 \mathrm{ml} \\
\text { (from a stock solution } 1.5 \mathrm{mg} \text { diluted in } 1 \\
\text { litre distilled water) }\end{array}$ & $145.60 \pm .92$ & $\begin{array}{l}137.20 \pm 1.12^{* *} \\
5.76 \% \downarrow\end{array}$ & $\begin{array}{l}138.40 \pm 1.22 * \\
4.94 \% \downarrow\end{array}$ \\
\hline $\mathrm{D}$ & $\begin{array}{l}\text { Lead acetate@20mg/kg b.wt plus } \\
\text { Vitamin } B_{6} @ 45 \mathrm{mg} / \mathrm{kg} \text { b.wt. dissolved in } \\
5 \mathrm{ml} \text { dist. Water. }\end{array}$ & $152.00 \pm 1.67$ & $\begin{array}{l}140.00 \pm 1.27 \\
7.89 \% \downarrow\end{array}$ & $\begin{array}{l}130.60 \pm 1.04 * \\
14.07 \% \downarrow\end{array}$ \\
\hline $\mathrm{E}$ & $\begin{array}{l}\text { Lead acetate @ } 20 \mathrm{mg} / \mathrm{kg} \text { b.wt } \\
\text { plus sodium selenite } 5 \mathrm{ml} \text { (from a stock } \\
\text { solution } 1.5 \mathrm{mg} \text { diluted in } 1 \text { litre distilled } \\
\text { water) plus Vitamin } \mathrm{B}_{6} @ 45 \mathrm{mg} / \mathrm{kg} \text { b. wt. } \\
\text { dissolved in } 5 \mathrm{ml} \text { dist. Water. }\end{array}$ & $153.00 \pm 2.00$ & $\begin{array}{l}152.00 \pm 1.87 \\
.65 \% \downarrow\end{array}$ & $\begin{array}{l}152.40 \pm 2.15 \\
.91 \% \downarrow\end{array}$ \\
\hline
\end{tabular}

Values above represent the mean $+\mathrm{SE}$ of 5 rats.

** Significantly decreased $(\mathrm{p}<0.01)$

* Significantly decreased $(\mathrm{p}<0.05)$

$\downarrow$ Percent decrease

A Percent increase

N.B.: $(* *, *, \downarrow$ these parameters are applicable for the all tables next).

\section{Total Erythrocytes Count (TEC)}

Rats of group-A (control), the erythrocyte count was almost normal during experimental period. In group B (lead acetate treated group), C and D, the total erythrocyte count was significantly decreased on $28^{\text {th }}$ day of treatment but in group D at $14^{\text {th }}$ day of treatment the mean reduction of TEC was not statistically significant. However, in group E, very few TEC was reduced throughout the experiment which was statistically not significant. 
Effects of selenium and vitamin $b_{6}$ with their combination in lead acetate induced toxicities in rats

Table 2. Effects of sodium selenite, vitamin $\mathrm{B}_{6}$ and a combination of sodium selenite plus vitamin $\mathrm{B}_{6}$ in lead induced toxicities on TEC (million / cu.mm) and TLC (Thousand /cu. mm)in rats

\begin{tabular}{|c|c|c|c|c|}
\hline \multirow{2}{*}{ Group } & \multirow{2}{*}{ Dose } & \multicolumn{3}{|c|}{ TEC count (million / cu.mm) } \\
\hline & & Day O & Day 14 & Day 28 \\
\hline A & Control & $8.86 \pm .02$ & $\begin{array}{l}8.89 \pm .07 \\
.33 \% \uparrow\end{array}$ & $\begin{array}{l}9.0 \pm 0.05 \\
1.58 \% 4\end{array}$ \\
\hline $\mathrm{B}$ & Lead acetate@20mg/kg b.wt dissolved in & $8.84 \pm .008$ & $\begin{array}{l}7.72 \pm .02 * * \\
12.67 \%\end{array}$ & $\begin{array}{l}6.76 \pm .02 * * \\
23.52 \%\end{array}$ \\
\hline $\mathrm{C}$ & $\begin{array}{l}\text { Lead acetate@20mg/kg b.wt dissolved in } \\
5 \mathrm{ml} \text { dist. water plus sodium selenite } 5 \mathrm{ml} \\
\text { (from a stock solution } 1.5 \mathrm{mg} \text { diluted in } 1 \\
\text { litre distilled water) }\end{array}$ & $8.61 \pm .04$ & $\begin{array}{l}7.94 \pm .01 * \\
7.78 \% \downarrow\end{array}$ & $\begin{array}{l}7.96 \pm .02 * \\
7.54 \% \downarrow\end{array}$ \\
\hline & Lead acetate @20mg/kg b.wt plus & $8.74 \pm .04$ & $8.21 \pm .02$ & $7.65 \pm .03 *$ \\
\hline $\mathrm{D}$ & $\begin{array}{l}\text { Vitamin } \mathrm{B}_{6} @ 45 \mathrm{mg} / \mathrm{kg} \text { b. wt. dissolved in } \\
5 \mathrm{ml} \text { dist. Water }\end{array}$ & & $6.06 \% \downarrow$ & $12.47 \% \downarrow$ \\
\hline $\mathrm{E}$ & $\begin{array}{l}\text { Lead acetate@20mg/kg b.wt } \\
\text { plus sodium selenite } 5 \mathrm{ml} \text { (from a stock } \\
\text { solution } 1.5 \mathrm{mg} \text { diluted in } 1 \text { litre distilled } \\
\text { water) plus Vitamin } \mathrm{B}_{6} @ 45 \mathrm{mg} / \mathrm{kg} \text { b. wt. } \\
\text { dissolved in } 5 \mathrm{ml} \text { dist. Water. }\end{array}$ & $8.81 \pm .02$ & $\begin{array}{l}8.75 \pm .02 \\
.68 \% \downarrow\end{array}$ & $\begin{array}{l}8.79 \pm .04 \\
.22 \% \downarrow\end{array}$ \\
\hline & & & count (thousan & \\
\hline & & Day O & Day 14 & Day 28 \\
\hline A & Control & $9.3 \pm .03$ & $\begin{array}{l}9.34 \pm .02 \\
.43 \% \boldsymbol{\varphi}\end{array}$ & $\begin{array}{l}9.41 \pm .01 \\
1.18 \% \boldsymbol{4}\end{array}$ \\
\hline $\mathrm{B}$ & Lead acetate @20mg/kg b.wt dissolved in & $9.71 \pm .008$ & $\begin{array}{l}8.31 \pm .005 \\
14.41 \% \downarrow\end{array}$ & $\begin{array}{l}6.91 \pm .003 * * \\
28.83 \% \downarrow\end{array}$ \\
\hline $\mathrm{C}$ & $\begin{array}{l}5 \mathrm{ml} \text { dist. water plus sodium selenite } 5 \mathrm{ml} \\
\text { (from a stock solution } 1.5 \mathrm{mg} \text { diluted in } 1 \\
\text { litre distilled water). }\end{array}$ & $9.20 \pm .02$ & $\begin{array}{l}0.40 \pm .02 \\
9.48 \% \downarrow\end{array}$ & $16.37 \% \downarrow$ \\
\hline & Lead acetate @20mg/kg b.wt plus & $9.20 \pm .01$ & $8.15 \pm .01 *$ & $7.1 \pm .002 *$ \\
\hline $\mathrm{D}$ & $\begin{array}{l}\text { Vitamin } \mathrm{B}_{6} @ 45 \mathrm{mg} / \mathrm{kg} \text { b. wt. dissolved in } \\
5 \mathrm{ml} \text { dist. Water }\end{array}$ & & $11.41 \% \downarrow$ & $22.82 \% \downarrow$ \\
\hline $\mathrm{E}$ & $\begin{array}{l}\text { Lead acetate@20mg/kg b.wt } \\
\text { plus sodium selenite } 5 \mathrm{ml} \text { (from a stock } \\
\text { solution } 1.5 \mathrm{mg} \text { diluted in } 1 \text { litre distilled } \\
\text { water). plus Vitamin } \mathrm{B}_{6} @ 45 \mathrm{mg} / \mathrm{kg} \mathrm{b} \text {.wt. } \\
\text { dissolved in } 5 \mathrm{ml} \text { dist. Water }\end{array}$ & $9.28 \pm .009$ & $\begin{array}{l}8.56 \pm .002 \\
7.76 \% \downarrow\end{array}$ & $\begin{array}{l}7.84 \pm .003 \\
15.51 \% \downarrow\end{array}$ \\
\hline
\end{tabular}

Total Leukocyte count (TLC)

In group A, TLC was almost normal throughout the experimental period. Total Leukocyte Count was significantly reduced in groups B and D to the extent of $28.83 \%$, and $22.82 \%$ respectively at $28^{\text {th }}$ day of treatment but in group B at $14^{\text {th }}$ day of treatment the mean reduction of TLC was non significant. In group C and $\mathrm{E}$ the TLC was reduced but not significant statistically and in group E the reduction was comparatively less than that of other groups.

\section{Hemoglobin (Hb) content}

Rats of group-A (control), exhibited normal hemoglobin content. In group B, Hb content was significantly decreased to the extent of $19.68 \%$ at $28^{\text {th }}$ day of treatment but this reduction was non significant at $14^{\text {th }}$ day of treatment. In group C, D and E, the hemoglobin content was decreased up to the extent of $8.37 \%, 5.52 \%$ and $7.44 \%$ respectively at $28^{\text {th }}$ day of treatment but this mean reduction of hemoglobin content was non significant. However, in group D, the reduction was less than that of other groups. 


\section{M.A. Ali and others}

\section{Packed Cell Volume (PCV)}

Total Packed Cell volume was reduced in all groups. Rats of group A (control), PCV was almost normal during experimental period. In group B and D, PCV was significantly decreased to the extent of $9.55 \%$, and $6.34 \%$ respectively at $28^{\text {th }}$ day of treatment and in group C and E, PCV was also reduced upto 5.34\%, and 4.07\% respectively but the reduction was statistically not significant.

\section{Biochemical parameters (SGOT and SGPT)}

The activities of SGOT were significantly elevated in group B, and D; to the extent of $98.63 \%$, and $68.40 \%$ respectively but in group $\mathrm{C}$ and $\mathrm{E}$, SGOT elevation was statistically non significant. Similarly SGPT was significantly elevated in group B and D to the extent of $176.11 \%$, and $18.20 \%$ respectively but in group C and E, SGPT elevation was statistically non significant. However, in group E, the elevation of SGOT and SGPT were less than that of other groups.

Table 3. Effects of sodium selenite, vitamin $\mathrm{B}_{6}$ and a combination of sodium selenite plus vitamin $\mathrm{B}_{6}$ in lead induced toxicities on GOT/AST and GPT/ALT in rats

\begin{tabular}{|c|c|c|c|c|c|}
\hline \multirow{2}{*}{\begin{tabular}{|l|} 
Name \\
of Test
\end{tabular}} & \multirow{2}{*}{ Group } & \multirow{2}{*}{ Dose } & \multicolumn{3}{|c|}{ ALT } \\
\hline & & & Day $\mathrm{O}$ & Day 14 & Day 28 \\
\hline \multirow{10}{*}{ SGOT } & A & Control & $51.80 \pm .53$ & $53.50 \pm .60$ & $58.44 \pm .61$ \\
\hline & $\mathrm{P}$ & otate $(2) 20 \mathrm{mo} / \mathrm{log}$ & $5213+11$ & $8215+35 * *$ & $10355+42 * *$ \\
\hline & D & $\begin{array}{l}\text { ml dist.water }\end{array}$ & $52.13 \pm .11$ & $57.58 \%$ & $98.63 \% 4$ \\
\hline & & Lead acetate@20mg/kg b.wt dissolved in 5 & $51.38 \pm .13$ & $67.34 \pm .25$ & $83.82 \pm .57$ \\
\hline & $\mathrm{C}$ & $\mathrm{ml}$ dist. water plus sodium selenite $5 \mathrm{ml}$ & & $31.06 \% 4$ & $63.13 \% 4$ \\
\hline & & $\begin{array}{l}\text { (from a stock solution } 1.5 \mathrm{mg} \text { diluted in } 1 \\
\text { litre distilled water). }\end{array}$ & & & \\
\hline & & Lead acetat@20mg/kg b.wt plus Vitamin & \multirow[t]{2}{*}{$51.72 \pm .21$} & $71.40 \pm .46^{*}$ & $87.10 \pm .39^{*}$ \\
\hline & $\mathrm{D}$ & $\begin{array}{l}\mathrm{B}_{6} @ 45 \mathrm{mg} / \mathrm{kg} \text { b. wt. dissolved in } 5 \mathrm{ml} \text { dist. } \\
\text { Water }\end{array}$ & & $38.07 \%$ & $68.40 \%$ 个 \\
\hline & \multirow{4}{*}{$\mathrm{E}$} & \multirow{4}{*}{$\begin{array}{l}\text { Lead acetate@20mg/kg b.wt } \\
\text { plus sodium selenite } 5 \mathrm{ml} \text { (from a stock } \\
\text { solution } 1.5 \mathrm{mg} \text { diluted in } 1 \text { litre distilled } \\
\text { water) plus Vitamin } \mathrm{B}_{6} @ 45 \mathrm{mg} / \mathrm{kg} \mathrm{b} \text {. wt. } \\
\text { dissolved in } 5 \mathrm{ml} \text { dist. Water }\end{array}$} & \multirow[t]{2}{*}{$51.40 \pm .10$} & $65.12 \pm .55$ & $80.19 \pm .42$ \\
\hline & & & & & \\
\hline \multirow{13}{*}{ SGPT } & & & \multicolumn{3}{|c|}{ AST } \\
\hline & & & Day O & Day 14 & Day 28 \\
\hline & A & Control & $76.00 \pm .71$ & $75.60 \pm .28$ & $75.80 \pm .32$ \\
\hline & & & & $.52 \% \downarrow$ & $.26 \% \downarrow$ \\
\hline & $\mathrm{B}$ & Lead acetate@20mg/kg b.wt dissolved in 5 & $77.00 \pm .02$ & $150.24 \pm$ & $212.61 \pm 2.0123 * *$ \\
\hline & $\mathbf{D}$ & ml dist.water & & $\begin{array}{l}.87 * * \boldsymbol{4} \\
95.11 \%\end{array}$ & $176.11 \%$ 平 \\
\hline & & Lead acetate@20mg/kg b.wt dissolved in 5 & $77.95 \pm .02$ & $85.77 \pm .53$ & $90.92 \pm 2.01$ \\
\hline & $\mathrm{C}$ & $\mathrm{ml}$ dist. water plus sodium selenite $5 \mathrm{ml}$ & & $10.03 \% 4$ & $16.63 \% 4$ \\
\hline & & litre distilled water). & & & \\
\hline & & Lead acetate@20mg/kg b.wt plus Vitamin & $77.62 \pm .85$ & $90.10 \pm .21 *$ & $94.90 \pm 1.31 *$ \\
\hline & $\mathrm{D}$ & $\begin{array}{l}\mathrm{B}_{6} @ 45 \mathrm{mg} / \mathrm{kg} \mathrm{b} \text {. wt. dissolved in } 5 \mathrm{ml} \text { dist. } \\
\text { Water }\end{array}$ & & $16.07 \%$ & $18.20 \% \boldsymbol{4}$ \\
\hline & & Lead acetate@20mg/kg b.wt & $77.20 \pm .25$ & $82.80 \pm .32$ & $86.52 \pm 1.54$ \\
\hline & $\mathrm{E}$ & $\begin{array}{l}\text { plus sodium selenite } 5 \mathrm{ml} \text { (from a stock } \\
\text { solution } 1.5 \mathrm{mg} \text { diluted in } 1 \text { litre distilled } \\
\text { water) plus Vitamin } \mathrm{B}_{6} @ 45 \mathrm{mg} / \mathrm{kg} \text { b. wt. } \\
\text { dissolved in } 5 \mathrm{ml} \text { dist. Water. }\end{array}$ & & $7.25 \% 4$ & $12.07 \% \boldsymbol{4}$ \\
\hline
\end{tabular}




\section{Gross pathological changes}

Through out the experiment (at day 0,14 and 28) gross pathological lesions in liver, kidney, heart, femur, spleen and intestinal muscle were recorded. Group wise lesions are listed below.

\section{Group A}

All the selected organs were apparently normal.

\section{Group B}

Liver : Highly congested, necrotic and become blackish in and slightly enlarged

Spleen, heart and kidney: Congested and blackish in appearance

Intestine: Severe-hemorrhagic enteritis was observed.

\section{Group C}

Liver: Pin point hemorrhage were found throughout the liver

Spleen, stomach and kidney: Lightly congested

Heart : Congestion was found around the coronary grove

Intestine: Slightly hemorrhages were found

\section{Group D}

Liver and kidney: Slightly congested

Intestine: Hemorrhagic enteritis was found

Heart : Congestion was found around the coronary band

Group E

Liver : Slight hemorrhage were found throughout the liver

Spleen and kidney: Spleen and kidney were slightly congested

\section{DISCUSSION}

\section{Toxic signs}

In group B (lead acetate alone) the toxic signs e.g. anxiety, indigestion, fatigue, muscle tremor, ataxia, loss of muscle coordination, loss of body weight, ruffled hair coat, decreased feed intake, irritability, slight paralysis at the posterior region were observed. Rats of group $\mathrm{C}$ (sodium selenite), D (vitamin $\mathrm{B}_{6}$ ) and group $\mathrm{E}$ (sodium selenite + vitamin $B_{6}$ ) showed mild toxic sign i.e. slight hemorrhage and congestion were found in liver, kidney, spleen and heart. However, the toxic sign were very mild in group E. Toxic signs observed in the present experiment were almost similar to the findings of other researcher such as Begum (2004), Haque (2005) and Klauder and Petering, (1975) who found anxiety, indigestion, muscular incoordination, ruffled hair coat, posterior paralysis, irritability, fatigue, ataxia, etc. after administration of lead acetate. In addition the researchers studied the protective effect of ascorbic acid, thiamine, spirulina, vitamin E, zinc sulfate following administration, in lead acetate induced toxicities in rats and found encouraging result i.e. the symptom of lead acetate was reduced like finding of the present study. It is well known that the inhibition of delta amino laevulinic acid dehydrates (ALAD), inhibition of haeme synthesis, and inhibition of transport protein (transferrin) synthesis and penetration of blood brain-barrier might be responsible for causing toxicity of lead acetate in rat. However in the present research mechanism of induction of toxicity was not studied. But it seems that the toxicity appeared followed the mechanism.

\section{Effect on body weight}

The findings of weight reducing in lead toxicity in present experiment were all most similar to the findings of Teijon et al. (2006) and Aseth et al. (1995) who found the body weight loss in lead induced toxicity in rats. Szymezak et al. (1983) reported that body weight gain and blood hemoglobin level were reduced after intoxicated with lead in a dose of $400 \mathrm{mg} / \mathrm{kg}$ of the fodder. Improvement of body weight occurs in group $\mathrm{E}$ (treated with sodium selenite + vitamin $\mathrm{B}_{6}$ ), may be due to protective and therapeutic role of sodium selenite + vitamin $\mathrm{B}_{6}$, against lead toxicity in rats (Bhattacharjee et al., 2003). The reduction of body weight of group $\mathrm{B}$ might be due to the interruption in absorption and metabolism of feed nutrients essential for health (Marija et al., 2004). 


\section{M.A. Ali and others}

\section{Effect on Hematological parameter}

A. Total Erythrocyte Count (TEC)

Rats of group E (lead acetate + sodium selenite + vitamin $B_{6}$ ) reduction of Total Erythrocytes Count were very low and gradually progressed and this improvement may be due to the protective role of combined action of sodium selenite and vitamin $\mathrm{B}_{6}$. The reduction of Total Erythrocyte Count might be due to the depressing effects of lead acetate on the hematopoietic organs of the body or might adversely affect the haem synthesis in the body during continuous administration of lead acetate orally. The present findings are almost similar to findings of Miniuk et al. (1989), Teijon et al. (2006) and Purser et al. (1983) where they found progressive decrease of Packed Cell Volume concentration, hemoglobin concentration and Erythrocyte concentration.

\section{B. Total Leukocyte Count (TLC), Hemoglobin (Hb) and Packed Cell Volume (PCV)}

The reasons of alteration of hematological parameters following lead acetate administration could not be explained fully due to the lack of available literatures. However, from the present study it is assumed that toxic effect of lead acetate on hemopoietic system may be responsible for changing the hematological parameters in the present study. In accordance to the present findings purser et al. (1983) observed that following lead acetate administration there was a moderate decrease in $\mathrm{Hb} \%$. Similarly, Flora and Tandon (1986) observed the gradual decrease of hemoglobin content after lead acetate administration and Szymezak et al. (1983) observed that Hb level was reduced after intoxication with lead acetate in dose of $400 \mathrm{mg} / \mathrm{kg}$ of the fodder.

\section{Biochemical parameters}

In group- E the elevation of SGOT and SGPT was less than that of other groups and the toxic sign was mild because sodium selenite and vitamin $\mathrm{B}_{6}$ may have some protective role against lead toxicity. Aspartate transaminase (AST) is widely used to assess the liver function. ALT is a cytoplasmic enzyme while AST is found in both cytoplasmic and mitochondria. SGPT or ALT is increased in acute hepatitis (viral or toxic), Jaundice, liver cirrhosis. SGOT or AST is increased in myocardial infarction, liver diseases, liver cancer and liver cirrhosis. The changes of ALT and AST in this study are accorded with findings of Patil et al. (2007) and Mehta et al. (2002) who found acute hepatitis, jaundice, liver cirrhosis etc.

\section{Gross pathological changes in some organs}

The visceral organs were apparently normal in the rats group- A (control group) but in the rats group B, severe congestion and blackish discoloration with enlargement of liver, kidney, spleen and rose red inflammation of the stomach mucosa were observed. Severe hemorrhagic enteritis also found in intestine. In the rats of group $\mathrm{C}$ and $\mathrm{D}$, the changes were slightly different to the group B. But in group E, the changes were comparatively less than others. There are non specific observation are observed in all groups. However, gross pathological changes observed in present experiment were almost similar to the finding of some other researchers such as Dhar and Banerjee, (1983) who found enlargement of liver and Purser et al. (1983) who found intra nuclear inclusions in the renal tubular cells of cynomolugus, monkey as were focal areas of myelin degeneration in the ulnar and sciatic nerves.

\section{CONCLUSION}

It is concluded that the treatment with sodium selenite in lead induced toxicity is much more effective in restoring lead induced hematological and biochemical alterations and in mobilizing of lead from tissues. The effectiveness of sodium selenite together with vitamin $\mathrm{B}_{6}$ was the highest and then followed by sodium selenite and vitamin $\mathrm{B}_{6}$. Further descriptive study is needed that will be beneficial for human being and for animal.

\section{REFERENCES}

1. Anguelov A, Hristev H, Belchev L and Chichovska M (2002).. Effect of antidote therapy on glutathione, malonic aldehyde and phospholipids in liver of lead intoxicated rats. Bulgarian Journal of Agricultural Science. 8(4): 445-448.

2. Aseth J, Jacobsen D, Andersen O and Wickstron E (1995). Treatment of mercury and lead poisoning with dimercaptosuccinic acid (DMSA) and sodium dimercapto-propanesulfonate (DMPS). Analyst 12o:853.

3. Begum $\mathrm{F}$ (2004). Effects of ascorbic acid, thiamin and their combination in lead induced toxicities in long Evans rats. $A$ thesis of M. S. in Pharmacology, submitted to BAU, Mymensingh. 
Effects of selenium and vitamin $b_{6}$ with their combination in lead acetate induced toxicities in rats

4. Bhattacharjee CR, Dey S and Goswami P (2003). Protective role of ascorbic acid against lead toxicity in blood of albino mice as revealed by metal uptake, lipid profiles, and ultrastructural features of erythrocytes. : Bulletin of Environmental Contamination and Toxicology. 70(6): 1189-1196.

5. Bob J and The Texas Farm Bureau (2004). Lead poisoning in cattle. Texas Farm Bureau Radio Network

6. Coffin DL (1955). Manual of Veterinary Clinical Pathology. 3rd Edn. Comstock Publishing Association, Inc, Ithaca, New York.

7. Deneke U and Rittersdorf W (1984). Evaluation of the Refluquant GPT (ALT) reagent carries with Reflotron. Clin. Chem., 30: 1009.

8. Deneke U, Rittersdorf W and Werner W (1985). Performance data of Reflotron-SGOT (AST) dry Chemistry test for Reflotron. Clin. Chem. 31: 19-21.

9. Dhar A and Banerjee PK (1983). Impact of lead on nucleic acids and incorporation of Icbelled amino acid into protein. Int. J. Vitam. Nutri. Res. 53 (3): 349-354.

10. Flora SJ and Tandon SK (1986). Preventive and therapeutic effects of thiamine, ascorbic acid and their combination in lead intoxication. Acta. Pharmacol. Toxicol. (Copenh) 58(5): 374-378.

11. Haque MM (2005). Effects of calcium carbonate, potassium iodide and zincsulfate in lead induced toxicities in mice. A thesis of M.S. in Pharmacology, BAU, Mymensingh.

12. Klauder DS and Petering G (1975). Protective value of dietary copper and iron against some toxic effects of lead in rats. Environmental Health Perspectives. 12: 77-79.

13. Lamberg SL and Rothstein R (1977). Laboratory Manual of Hematology and Urinalysis. Avi. Publishing Company, Inc, West Port Connecticut, U.S.S.R

14. Marija V, Piasek M, Blanusa M, Saric M, Juresa D and Kostial K (2004). Succimer treatment and calcium supplimentation reduce tissue lead in suckling rats.J. Appl. Toxicol. 24(2): 123-128.

15. Mehta A, Kajnnan GM, Dube SN, Pant BP, Pant SC and Flora SJS (2002). Hematological, hepatic and renal alterations after repeated oral or intraperitoneal administration of monoisoamyl DMSA. I. Changes in male mice. J. Apple. Toxicol. 22(6): 359-369.

16. Miniuk K, Moniuszko JJ, Kulikowska E and Omieljaniuk N (1989). The interactions of copper, lead and ethanol in rats: effects in some biochemical parameters of blood. Pol. J. Pharmacol. Pnarm. 41(3):273-280.

17. Patil AJ, Bhagwat VR, Patil JA, Dongre NN, Ambekar JG and Das KK (2007). Occupational lead exposure in battery manufacturing workers, silver jewelry workers, and spray painters in western Maharashtra (India) :effect on liver and kidney function. J Basic clin Physiol Pharmacol. 18(2): 87-100.

18. Patrick L (2006). The role of free radical damage and the use of antioxidants in the pathoalogy and treatment of lead toxicity. Altern Med. Rev. 11 (2): 114-127.

19. Purser DA, Berrill KR and Majeed SK (1983). Effects of lead exposure on peripheral nerve in the cynomolgus monkey. Br. J. Jntl. Med. 56: 33-36.

20. Suzuki T and Yoshida L (1979a). Effect of dietary supplementation of iron and ascorbic acid on lead toxicity in rats. $J$. Nutr. 109: 982-988.

21. Szymezak J, Zechalko A and Biernat J (1983). Effect of fodder fat type on blood plasma lipids in rats intoxicated with led. Bromatol. Chem. Toksykol. 16(2): 98-94.

22. Tandon SK. and Singh D (2000). Role of vitamins in the treatments of lead intoxication. J. Trace Elem. Exp. Med 13: 305-315.

23. Teijon C, Olmo R, Blanco D, Romero A. and Teijon JM (2006). Low doses of lead: effects on reproduction and development in rats. Biol Trace Elem Res. 111(1-3):151-165. 